\title{
A literature review on osteoporosis risk factors and prevention: the importance of an early approach
}

Uma revisão da literatura sobre fatores de risco e prevenção da osteoporose: a importância de uma abordagem precoce

Una revisión de la literatura sobre los factores de riesgo y la prevención de la osteoporosis: la importancia de un enfoque temprano

Mellânia Rodrigues Goveia ORCID: https://orcid.org/0000-0003-0937-7472

Universidade Anhanguera, Brasil

E-mail: goveiamellania@gmail.com

Gleyson Murillo Aguilera Moraes ORCID: https://orcid.org/0000-0002-9134-2609

Universidade Anhanguera, Brasil

E-mail: murillomoraes_@hotmail.com

Marco Antônio de Souza Borges Tavares

ORCID: https://orcid.org/0000-0002-9552-6990

Universidade Federal de Mato Grosso do Sul, Brasil

E-mail: mantoniosouzza@gmail.com

Tauanne Fernanda dos Santos

ORCID: https://orcid.org/0000-0002-7075-8031

Universidade Anhanguera, Brasil

E-mail: tauannef@icloud.com

Lanúbia Garcia de Araújo Vasconcelos ORCID: https://orcid.org/0000-0003-0320-0510

Universidade Anhanguera, Brasil

E-mail: lanubiagarcia@hotmail.com

Maíra Lima Miacava

ORCID: https://orcid.org/0000-0003-4365-2212

Universidade do Estado de Mato Grosso, Brasil

E-mail: maira.miacava@gmail.com

Rafaela Santos Ribeiro

ORCID: https://orcid.org/0000-0003-0890-9756

Universidade Anhanguera, Brasil

E-mail: rafaelaribeiro101@hotmail.com

Carlos Henrique de Castro

ORCID: https://orcid.org/0000-0001-5947-6407

Universidade Federal de Rondônia, Brasil

E-mail: cahecastrocel@gmail.com

Letícia Giora Stutz

ORCID: https://orcid.org/0000-0002-9458-2798

Universidade Estadual de Londrina, Brasil

E-mail: leticia_stutz@hotmail.com

João Nelson dos Santos Rodrigues Filho ORCID: https://orcid.org/0000-0002-2192-0872

Universidade Anhanguera, Brasil

E-mail: joaonelsonsrf@gmail.com

Silvio Rodrigo Arevalos Davalos ORCID: https://orcid.org/0000-0002-7904-0042 Universidade Federal de Mato Grosso do Sul, Brasil

E-mail: silvioarevalos6@gmail.com

Natália Della Roveri Rodrigues

ORCID: https://orcid.org/0000-0001-9815-1672

Universidade de Marília, Brasil

E-mail: natyrovery@hotmail.com

\begin{abstract}
Osteoporosis is a condition characterized by deterioration of bone microarchitecture resulting in loss of total bone mass, decreased tissue resistance and increased susceptibility to fractures. The study in question aimed to analyze and
\end{abstract}


debate the risk factors and the effectiveness of forms of prevention related to osteoporosis, given their implication for the general population and the need to disseminate safe and effective forms of behavioral management that can contribute to the decrease in the condition, mainly in the most susceptible individual. For this, 42 articles indexed in Bireme, PubMed, Scielo and UpToDate platforms were selected for discussion of the topic. Thus, it was concluded that the need for active investigation of risk factors by health professionals, as well as the encouragement of preventive practices, especially in the population with higher incidence of the disease.

Keywords: Osteoporosis; Perception; Knowledge; Patients.

\section{Resumo}

A osteoporose é uma patologia que se caracteriza por deterioração da microarquitetura óssea resultando em perda da massa óssea total, diminuição da resistência do tecido e aumento da susceptibilidade a fraturas. O estudo em questão objetivou analisar e debater os fatores de risco e a eficácia das formas de prevenção relativas à osteoporose, visto a implicação destes para a população em geral e a necessidade de disseminar formas seguras e efetivas de manejo comportamental que possam contribuir para com a diminuição da afecção, principalmente, no indivíduo mais susceptível. Para isso, selecionou-se 42 artigos indexados nas plataformas Bireme, PubMed, Scielo e UpToDate, para discussão do tema. Desta forma, concluiu-se que, necessidade de investigação ativa dos fatores de risco por parte dos profissionais de saúde, bem como o incentivo às práticas preventivas, principalmente na população de maior incidência da doença.

Palavras-chave: Osteoporose; Percepção; Conhecimento; Pacientes.

\section{Resumen}

La osteoporosis es una patología caracterizada por el deterioro de la microarquitectura ósea que resulta en la pérdida de masa ósea total, disminución de la resistencia tisular y aumento de la susceptibilidad a las fracturas. El estudio en cuestión tuvo como objetivo analizar y debatir los factores de riesgo y la efectividad de las formas de prevención relacionadas con la osteoporosis, dada su implicación para la población en general y la necesidad de difundir formas seguras y efectivas de manejo conductual que puedan contribuir a la disminución de la condición, principalmente en el individuo más susceptible. Para ello, se seleccionaron 42 artículos indexados en las plataformas Bireme, PubMed, Scielo y UpToDate para la discusión del tema. Así, se concluyó que la necesidad de una investigación activa de los factores de riesgo por parte de los profesionales de la salud, así como el fomento de prácticas preventivas, especialmente en la población con mayor incidencia de la enfermedad.

Palabras clave: Osteoporosis; Percepción; Conocimiento; Pacientes.

\section{Introduction}

According to the International Osteoporosis Foundation (2017), osteoporosis (OP), which literally means porous bone, is a disease in which bone density and quality are reduced. As bones become more porous and fragile, there is an increased risk of fractures. Bone loss occurs silently and progressively. There are usually no symptoms until the first fracture occurs. For Alissa et al. (2015) osteoporosis is a chronic skeletal disease characterized by low bone mass and deterioration of bone tissue microarchitecture.

The pathology in question is characterized by compromised bone strength, predisposing to a greater risk of fracture, pain, deformity and physical disability. Bone strength reflects the integration between bone density and bone quality, which in turn is determined by several factors: internal trabecular microarchitecture, bone remodeling rate, macroarchitecture, microdamage accumulation, degree of mineralization and matrix quality (Freitas, 2016).

With a multifactorial etiology, osteoporosis can originate from natural causes such as menopause, and some factors are considered risk factors, such as age, white or Asian ethnicity, low body mass index, family history, dietary inadequacies (high caffeine consumption, low calcium intake, low vitamin D intake), insufficient sun exposure, inadequate lifestyle (sedentary lifestyle, alcohol abuse, smoking), previous family history of fractures, use of some medications such as glucocorticoids and anticonvulsants, and presence of some inflammatory diseases and chronicles (Fernandes, et al., 2015).

The aging of the Brazilian population is reflected in the more than 16 million Brazilians over the age of 60, projected to exceed 50 million in 2050. Consequently, the chances of occurrence of diseases related to the aging of the population, such as osteoporosis, increase. (Martini, et al, 2006). 
Brazilian population-based studies indicate that the prevalence of this pathology ranges from 4.4 to $27.4 \%$, depending on the methodology and age group surveyed (Martini, et al, 2009; Pinheiro, et al, 2010; Baccaro, et al., 2013). Developed researches have evidenced the factors associated with osteoporosis, such as: history of the pathology in the family, low education, sedentary lifestyle, consumption of alcoholic beverages and a diet low in calcium (Tatsuno et al 2013). Regarding the factors pointed out in current studies, the following are cited: longer menopause, sarcopenia, use of caffeine during menopause, in addition to self-perceived health as poor, arthrosis, problems in maintaining balance, advanced age and current smoking (Pinheiro et al, 2010; Baccaro et al, 2013) However, Martini et al. (2009) assess that the prevalence and factors associated with OP are still not sufficiently clarified. What clarifies the importance of clarifying risk factors and their possible forms of prevention.

\section{Methodology}

The study is a qualitative research of the narrative review type (Koche, 2011), in which the methodology used was a literature search based on literature already published in the following databases: Bireme, PubMed, Scielo and UpToDate. The articles were obtained using the following descriptors: "Osteoporosis"; "Risk factors for osteoporosis"; "Prevention of osteoporosis". In this sense, 395 articles were found, however, it is necessary to review all the material, in view of the quality of the writing, content and bibliographic references (Pereira, et al., 2018). frame between the years 2013 to 2021, to review on the topic; as well as articles that answered the following guiding question: "What are the main risk factors and how to prevent them in the case of osteoporosis". Finally, a total of 42 articles were obtained, all discussed here.

\section{Literature Review}

Osteoporosis is the most frequent of osteometabolic diseases and its study has been especially motivated due to the important repercussions in relation to the morbidity and mortality of individuals with this condition, and for this reason it is currently considered a serious public health problem (Lanna, et al. al, 2003).

With no symptoms, osteoporosis causes more than 8.9 million fractures annually worldwide, resulting in an osteoporotic fracture every 3 seconds, according to the International Federation of Osteoporosis (IOF). It is estimated that the disease affects 200 million women worldwide, across the planet, one in three women over 50 will suffer osteoporotic fractures, as well as one in five men over 50 years. The few studies carried out with men in Brazil show that the prevalence of the pathology in the male population over 65 years of age is around 15\%, while the prevalence of fractures is between 12 and $20 \%$. (Maeda, 2017).

Brazil is a country with a great ethnic mixture with heterogeneous regional distribution. Thus, the prevalence of osteoporosis in Brazilian studies can range from 6 to 33\% depending on the population and other variables evaluated (Marinho et al., 2015).

It is known that even if osteoporosis occurs in both sexes, women stand out in the development of the disease due to aspects such as the greater number of this population, physiological issues, speed of bone loss, hormonal decrease that impacts on estrogen levels and, the consequent menopausal process (Melo, 2017). In addition, there is the natural factor of advancing age, which also contributes to the higher prevalence of osteopenia and osteoporosis in this population (Mazocco; Chagas, 2017).

According to the Brazilian Society of Endocrinology and Metabolism approximately ten million Brazilians suffer from the disease and one in four women over fifty develops it (Santiago; Vieira; Nunes, 2018). Silva et al. (2018) highlight that one of the consequences of natural or induced ovarian failure is osteoporosis, thus increasing the risk of fractures. Osteoporosis is a major complication of aging in women and is strongly associated with sex hormone deficiency, but it can also be caused by 
alcoholism or treatment with high doses of corticosteroids.

Excess caffeine also has the potential to predispose osteoporosis in postmenopausal patients. The studies by Hyassat et al. (2017) demonstrated that women at this stage of life with a daily caffeine intake greater than $300 \mathrm{mg} /$ day were at greater risk of developing osteoporosis. Studies have shown that the pathophysiology of the process is based on the direct action of caffeine on osteoblasts and osteocytes, disturbing the process of differentiation, multiplication, mineralization and production of the bone matrix, leading to apoptosis of these cells (Chang, 2013; Liu, 2011). Furthermore, it is mentioned that caffeine can increase the differentiation of osteoclasts, resulting in greater loss of calcium in the urine, a fact that can predispose to the formation of urinary stones (Lacerda, 2010). All of these mechanisms can contribute to the decrease in bone density caused by high caffeine consumption.

In addition to menopause, another risk factor that stands out is sarcopenia; such pathology together with osteoporosis consist of diseases that reinforce each other in terms of negative results. With the progressive senescence of the population, there has been a progressive increase in the incidence of musculoskeletal disorders, which corroborates the close association between muscle and bone; it turns out that both are not only tangent adjacent to their anatomical position, they are also known to share common endocrine and paracrine regulation, as well as the pathways that regulate their molecular signaling (Bonewald, et al., 2013; Girgis, 2015). These aspects are relevant because the loss of bone mass, muscle function and strength, when added to the senility process, is significantly enhanced with regard to the occurrence of osteoporotic fractures. Allied to this, age-related decrease in bone mass quality and composition also acts as a sarcopenia maximizer, a fact that proves that both pathologies feedback (Edwards, et al., 2015; Oliveira and Vaz, 2015). Thus, it can be seen that the increased risk of fracture in people with associated osteoporosis and sarcopenia is due to the reduction in muscle strength and mass, as well as the bone mineral density and decreased body mobility (Tarantino, et al., 2016; Steihaug et al., 2017). The work developed by Marques and Queirós (2018) and by Yeung et al. (2019) accused that elderly people with sarcopenia have a triple chance of falling, when compared to those who do not have the pathology in question. Furthermore, there is evidence that sarcopenia is closely linked to fractures, which is aggravated when it occurs in patients with some degree of osteopenia or osteoporosis.

Prevention of osteoporosis consists of lifestyle measures and pharmacological therapy taking into account that bone strength reflects the integration of bone mineral density (BMD) and other bone properties that are collectively called "bone quality". Adult BMD is determined by peak bone mass and subsequent bone loss. As the BMD measured by dual energy X-ray absorptiometry (DXA) decreases, the risk of fracture increases as a continuum, without "fracture threshold". Thus, prevention of low bone mass is aimed at maximizing peak bone mass and minimizing the rate of bone loss, with the ultimate goals of maintaining bone strength and preventing fractures (Lewiecki, 2021).

Some authors consider senile osteoporosis a "pediatric disease" taking into account the importance of reaching the maximum peak potential bone mass in childhood in order to lessen the effects of bone loss later in life. Preventing bone loss is preferable to treatment once established pathology has occurred, because the degradation of bone microarchitecture associated with bone loss is largely irreversible. Treatment may stabilize or increase BMD and reduce fracture risk, but is unlikely to fully restore bone quality and bone strength (Kiel, 2021).

The time of peak bone mass is not known with certainty, but it probably occurs in the third decade of life in most individuals. However, for maximum bone mass to be established, good nutrition from childhood is necessary, together with regular physical activities, with the particular benefit of high-impact exercise, associated with a smoking-free life and low-tomoderate alcohol consumption. Furthermore, the administration of medications that are known to be harmful to skeletal health, such as glucocorticoids and anticonvulsants, should be avoided or minimized in dose and duration (Behringer, et al, 2014).

As for pharmacological therapy, there is still no means available to maximize peak bone mass, but rather to stabilize bone mineral density and/or reduce the rate of bone loss, which is the main objective in preventing osteoporosis. Lewiecki 
(2021) considers that the approach to preventing osteoporosis should be done in a pyramid shape, the first level being nutrition, physical activity and prevention of falls, the second level addressing medications and diseases associated with bone loss or osteoporosis and by finally, the third level addressing pharmacological therapy.

Age-related bone loss is known to begin shortly after peak bone mass for both sexes. Therefore, for most patients with low bone mass or osteopenia, it is not suggested to use pharmacological therapy to prevent bone loss. With the exception of those patients at high risk of fracture, who will, however, benefit from pharmacological therapy (Rosen; Drezner, 2021).

Based on extensive experience in use, safety and proven efficacy in reducing vertebral, non-vertebral and femoral fractures, bisphosphonates are considered first-line agents in the treatment and prevention of postmenopausal osteoporosis (Caires, et al., 2017).

From this class, the most used medications are: alendronate at a dose of $5 \mathrm{mg} / \mathrm{day}$ or $35 \mathrm{mg} / \mathrm{week}$; risedronate - 5 $\mathrm{mg}$ /day or $35 \mathrm{mg} /$ week; ibandronate - $150 \mathrm{mg} / \mathrm{month}$ and zoledronic acid $-5 \mathrm{mg}$ IV once every 2 years. Among the bisphosphonates that have the best cost/benefit, in addition to greater availability of long-term safety data, are alendronate and risedronate, thus becoming the most suitable medications for the prevention of osteoporosis (Rosen, 2021). With regard to alendronate, the prevention dose used is equivalent to half the dose for the treatment, while the prevention and treatment doses are the same for the rest of the bisphosphonates. Another particularity of application is found in prevention with the use of zoledronic acid, in which the interval of doses for prophylaxis is every two years, and in treatment the dose is annual (Finkelstein; Yu, 2021).

Potent antiresorptive agents increase BMD Discontinuation of bisphosphonates after 3 years (zoledronic acid) to 5 years (alendronate) is justified for patients who, at the end of this period, present a low risk of fracture. However, those who persist with a femoral T-score $\leq-2.5$ after starting treatment should have this treatment continued for up to 6 (zoledronic acid) to 10 years (alendronate) (Caires et al., 2017). Medications in this class of drugs in young and elderly postmenopausal women have been shown to reduce the risk of fracture in older postmenopausal women. However, Radominski, et al. (2017), reinforce that due to the high prevalence of secondary causes of osteoporosis, many of them subclinical, it is recommended for all patients before starting any treatment a minimum laboratory evaluation that includes complete blood count, calcium, phosphorus, alkaline phosphatase, thyroid function and serum $25(\mathrm{OH})$ vitamin D measurement, 24-hour calciuria, in addition to plain lateral radiography of the thoracic and lumbar spine and measurement of BMD in the lumbar spine and proximal femur.

Another way to prevent osteoporosis is with the use of calcitonin, but it is not used as a first-line therapy due to the fact that there are more effective drugs, such as bisphosphanates. Calcitonin is a 32-amino acid peptide that binds to osteoclasts and inhibits bone resorption. There are calcitonins from several species that have been shown to be compatible with those of humans, as well as human calcitonin; however, the most effective is salmon calcitonin, it has a high affinity (40 times that of human calcitonin) and a slow clearance rate. Currently, the only calcitonin used is human, but numerous clinical trials have shown the best efficacy of salmon calcitonin (Rosen, 2020).

Another way to prevent bone loss, specifically in postmenopausal patients is the use of estrogen, however, it is not a first-line treatment due to concerns about adverse effects. However, in women who chose hormone replacement therapy, estrogen showed reductions in bone loss and fracture risk, in addition to benefits related to menopausal symptoms (Manson, et al, 2013).

As for sarcopenia and its relationship with osteoporosis, there are effective measures that can be applied to delay or even reverse the progression of sarcopenia in the elderly. Due to the positive role of resistance exercises in human muscle mass, numerous studies have inserted resistance exercises in the treatment of sarcopenia and, consequently, osteoporosis. Authors demonstrated that a 12- to 16-week cycle of resistance training increased individuals' thigh circumference by $11.4 \%$ 
and muscle volume by 3.8\% (Van Roie et al., 2013). Most interestingly, the authors proved that muscle growth caused by resistance exercise can occur at any age, even in the elderly (Westcott, 2009). In addition to resistance exercise, exercise in water can improve muscle balance and muscle strength, in addition to providing adequate postural mobility (Irandoust, et al., 2019). Regular physical activity can act on the clearance of body fat, improve musculoskeletal control, reduce low back pain, and improve the quality of balance and walking speed in the elderly (Irandoust, et al., 2019). Similarly, Pilates exercise can increase body fat mass and improve muscle atrophy, balance, and walking speed in middle-aged inactive women (Seghatoleslami, et al., 2018). Skeletal muscle atrophy and skeletal muscle strength have been shown to significantly improve in elderly patients with sarcopenia after adequate treatment with vitamin D and amino acids (Seeliger, et al., 2015). Authors have pointed out that combining resistance exercise with protein and vitamin D supplements is the most effective way to improve sarcopenia or myasthenia in the elderly (Eshaghi, et al., 2020). However, the complex pathogenesis of sarcopenia and several influencing factors have not been fully understood.

Regarding how food can help in the osteoporotic prevention process, the Mediterranean Food Pattern or Mediterranean Diet (DM) has beneficial effects on many pathologies, including osteoporosis. The incidence of osteoporosis is lower in the Mediterranean area, which is mostly attributed to the specific dietary pattern of the area. The anti-inflammatory, antioxidant and alkalizing properties of its components contribute to the "bone-sparing" effect. Some studies demonstrate that adherence to traditional DM has been associated with high bone mineral density and reduced fracture risk. Thus, an association between key individual characteristics of the Mediterranean Food Pattern and a reduction in the incidence of osteoporosis or fracture occurrence is demonstrated, such as high consumption of fruit, vegetables and olive oil, moderate to high consumption of fish and moderate intake of alcoholic beverages (Almeida, 2017).

The study by Savanelli (2017) showed a positive correlation between bone health status and adherence to DM. The results suggest that greater adherence to DM plays a beneficial role in bone health and confirm that a specific dietary approach, such as DM, can represent an important modifiable environmental factor for the prevention of osteoporosis. The same author also mentions that recent evidence has reported differences in the severity of osteoporosis in European Union countries, suggesting a lower incidence of the disease in the Mediterranean area. This effect was mainly attributed to the specific dietary pattern. In addition, Quattrini (2021) concluded, in a survey with a population of peri- and postmenopausal women, that the greater the adherence to DM, the greater the daily intake of calcium, which may, in part, explain the benefit of the diet for the pathology in question. Another point to be taken into account was highlighted by the study by Zupo (2020), in which it is argued that closer adherence to DM is independently associated with an increase in $25(\mathrm{OH}) \mathrm{D}$, suggesting that higher levels of vitamin D may contribute to the protective effect of DM on osteoporosis.

\section{Conclusion}

Based on the information presented here, it appears that osteoporosis is a pathology that makes bones more porous and fragile, thus increasing the risk of fractures, since bone loss occurs silently and progressively, commonly, without symptoms until the first fracture occurs. Thus, it is important to know the risk factors and act to minimize their intensity or even eliminate them partially (as in the case of sarcopenia due to the practice of resistance exercise) or totally (such as the exacerbated ingestion of caffeine). It turns out that the disease discussed here has no cure, only control of its progression, therefore, bringing to the debate the risk factors and ways to prevent the disease from occurring are of paramount importance to reduce the incidence levels of osteoporosis. Thus, there is a need for active investigation of risk factors by health professionals, as well as the encouragement of preventive practices, especially in the population with the highest incidence of the disease. Finally, the possibility of future research on the pathophysiology of osteoporosis is suggested, since, through a clear elucidation of them, it 
will be possible to act more effectively in the preventive aspect, as well as research that clarify the relationship between the factor's protection and osteoporosis, in order to explain possible means for the genesis of new treatments.

\section{References}

Alissa E. M., Alnahdi W. A., Alama N. \& Ferns G. A. (2015). Bone mineral density and cardiovascular risk factors in postmenopausal women withcoronary artery disease. Bonekey Rep. 11:4:758.

Almeida, M. \& Oliveira, A. (2017). Mediterranean and Atlantic food pattern: an approach to its key characteristics and health effects. Port Nutr Minutes, Porto, n. 11, p. 22-28,

Baccaro, L. F., Machado, V. S. S. M, Costa-Paiva, L., Sousa, M. H., Osis, M. J. \& Pinto-Neto, A. M. (2013). Factors associated with osteoporosis in Brazilian women: a population-based household survey. Arch Osteopores. 8(1-2): 138.

Behringer, M., Gruetzner S., McCourt M. \& Mester J. (2014). Effects of Weight-Bearing Activities on Bone Mineral Content and Density in Children and Adolescents: a meta-analysis. Journal Of Bone And Mineral Research, [S.L.], v. 29, no. 2, p. 467-478. Wiley. http://dx.doi.org/10.1002/jbmr.2036.

Bonewald, L. F., Kiel, D. P., Clemens, T. L., Esser, K., Orwoll, E. S. \& O'Keefe R. J. (2013). Forum on bone and skeletal muscle interaction: summary of the procedures of an ASBMR workshop. J. Bone Miner. Res. 28, 1857-1865. doi: 10.1002 / jbmr.1980

Caires, E. L. P., Bezerra, M. C., Junqueira, A. F. T. A., Fontenele, S. M. A., Andrade, S. C. A. \& dÁlva, C. B. (2017). Treatment of postmenopausal osteoporosis: a literature-based algorithm for use in the public health care system. Brazilian Journal of Rheumatology (English Edition), [S.L.], v. 57, no. 3, p. 254-263. Elsevier BV. http://dx.doi.org/10.1016/j.rbre.2017.01.001.

Edwards, M. H., Dennison, E. M., Aihie, S. A., Fielding, R. E. \& Cooper, C. (2015). Osteoporosis and sarcopenia in old age. Bone 80, 126-130. doi: 10.1016 / j.bone.04.016

Eshaghi, S., Morteza, T., Khadijeh, I., Knechtle, B. Nikolaidis, P. T. \& Chtourou, H. (2020). The effect of aerobic training and vitamin D supplements on neurocognitive functions in elderly women with sleep disorders. Biol. Rhythm Res. 51, 1-8

Fernandes, T. R. L., Oliveira, J. B., Lorencete, T. V. \& Amadei, J. L. (2015). Factors associated with osteoporosis in postmenopausal women. Semina: Biological and Health Sciences, Londrina, v. 36, no. 1, p. 93-106.

Freitas, E. V. \& P. Y. L. (2016). Treatise on Geriatrics and Gerontology. 4th ed. São Paulo: Guanabara Koogan.

Finkelstein, J.; YU, E. (2021). Treatment of osteoporosis in men. UpToDate.

Fortes, E. M., Raffaelli, M. P., Bracco, O. L., Takata, E. T. T., Reis, F. B., Santili, C. \& Castro, M. L. (2008). High Morbimortality and Low Diagnosis Rate of Osteoporosis in Elderly with Proximal Femur Fracture in the City of São Paulo. Arq Bras Endocrinol Metab.

International Osteoporosis Foundation. (2017). What is osteoporosis?. <https://www.iofbonehealth.org/what-is-osteoporosis>.

Irandoust, K., Taheri, M., Mirmoezzi, M., H'mida, C., Chtourou, H. \& Trabelsi, K. (2019). Effect of aquatic exercise on postural mobility in healthy elderly people with endomorphic somatotype. Int. J. Environ. Res. Public Health 16: 4387.

Girgis, C. M. (2015). Integrated therapies for osteoporosis and sarcopenia: from signaling pathways to clinical trials. Calcif. Tissue Int. 96, 243-255. doi: 10.1007 / s00223-015-9956-X

Hyassat, D., Alyan, T., Jaddou, H. \& Ajlouni, K. M. (2017). Prevalence and Risk Factors of Osteoporosis Among Jordanian Postmenopausal Women Attending the National Center for Diabetes, Endocrinology and Genetics in Jordan. Bioresearch Open Access, [S.L.], v. 6, no. 1, p. 85-93. Mary Ann Liebert Inc. http://dx.doi.org/10.1089/biores.2016.0045

Kiel, D. (2021). Falls: Prevention in community-dwelling seniors. UpToDate.

Lacerda, S. A., Matuoja, R. I., Macedo, R. M., Petenusci, S. O., Campos, A. A. \& Brentegani, L. G. (2010). Bone quality associated with daily coffee intake: biochemical, radiographic and histometric study. Braz J dental.

Lanna, C. M. M., Montenegro, Jr. R. M., Paula, F. J. A. (2003) Pathophysiology of Glucocorticoid-Induced Osteoporosis. Division of Endocrinology and Metabolism, Department of Internal Medicine, Faculty of Medicine of Ribeirão Preto - USP, SP.

Lewiecki, M. (2021) Prevention of osteoporosis. UpToDate.

Liu, S.H. (2011). Caffeine increases osteoclast differentiation from hematopoietic cells in bone marrow and reduces bone mineral density in growing rats. $J$ Orthop Res.

Maeda, S.S. (2017). Brazilian Society of Endocrinology and Metabolism. Know the osteoporosis numbers. <https://www.sbemsp.org.br/para-opublico/noticias/116-conheca-os-numeros-da-osteoporosis>.

Manson, J. E. Chlebowski, R. T., Stefanick, M. L, Aragaki, A. K., Rossouw, J. E., Prentice, R. L., Howard, G. A. B. V., Thomson, C. A., LaCroix, A. Z., Wactawski-Wende, J., Jackson, R. D., Limacher, M., Margolis, K. L., Wassertheil-Smoller, S., Beresford, S. A, Cauley, J. A., Eaton, C. B., Gass, M., Hsia, J., Johnson, K. C., Kooperberg, C., Kuller, L. H., Lewis, C. E., Liu, S., Martin, L. W., Ockene, J. K., O'Sullivan, M. J., Powell, L. H., Simon, M. S., Horn, L. V., Vitolins, M. Z. \& Wallace, R. B. (2013). Menopausal Hormone Therapy and Health Outcomes During the Intervention and Extended Poststopping Phases of the Women's Health Initiative Randomized Trials. Jama, [S.L.], v. 310, no. 13, p. 1353. American Medical Association (AMA). http://dx.doi.org/10.1001/jama.2013.278040. 
Marinho, B. C., Guerra, L. P., Drummond, J. B., Silva, B. C. \& Soares, M. M. (2015). The burden of osteoporosis in Brazil. Arq Bras Endocrinol Metab. 58(5): 434-43.

Martini, L. A., Moura, E. C., Santos, L. C., Malta, D. C. \& Pinheiro, M. M. (2009). Prevalence of self-reported diagnosis of osteoporosis. Brazil. Rev Public Health; 43(Suppl 2): 107-16.

Mazocco, L. \& Chagas, P. (2017). Association between body mass index and osteoporosis in women from northwestern Rio Grande do Sul. Rev Bras Reumatol, Palmeira das Missões, v. 57, no. 4, p. 299-305.

Melo, A. C. F., Nakatani, A. Y. K., Pereira, L. V., Menezes, T. L. \& Pagotto, V. (2017). Prevalence of self-reported musculoskeletal diseases according to demographic and health variables: a cross-sectional study of elderly people from Goiânia/GO. Cad Saúde Coletiva, Rio de Janeiro, v, 25, n.2, p. 138-143.

Oliveira A. \& VAZ C. (2015). The role of sarcopenia in the risk of osteoporotic hip fracture. Clin. Rheumatol. 34, 1673-1680. doi: 10.1007 / s10067-0152943-9

Pinheiro M.M., Ciconelli R.M., Jaques Nde O., Genaro P.S., Martini L.A. \& Ferraz M.B. The burden of osteoporosis in Brazil: regional data from fractures in adult men and women - the Brazilian Osteoporosis Study (BRAZOS). Re22v Bras Rheumatol. 50(2): 113-27.

Quattrini, S., Pampaloni, B., Gronchi, G., Giusti F. \& Brandi, M. L. (2021). The Mediterranean Diet in Osteoporosis Prevention: An Insight in a Peri- and Post-Menopausal Population. Nutrients 13, 531. https://doi.org/10.3390/nu13020531.

Radominski, S. C., Bernardo, W., Paula, A. P., Albergaria, B. H., Moreira, C., Fernandes, C. E., Castro, C. H. M., Zerbini, C. A. F., Domiciano, D. S., Wender ,M. C. O., Castro, M. L., Pereira, R. M. R., Maeda, S. F. \& Borba, V. Z. C. (2017). Brazilian guidelines for the diagnosis and treatment of postmenopausal osteoporosis. Brazilian Journal of Rheumatology (English Edition), [S.L.], v. 57, p. 452-466. Elsevier BV. http://dx.doi.org/10.1016/j.rbre.2017.07.001.

Rosen, H. (2020) Calcitonin in the prevention and treatment of osteoporosis. UpToDate.

Rosen, H. \& Drezner M. (2021). Overview of the management of osteoporosis in postmenopausal women. UpToDate.

Rosen, H. (2021) Bisphosphanate therapy for the treatment of osteoporosis. UpToDate.

Santiago, E. M. D., Vieira, F.S. \& Nunes, A. (2018). Osteoporosis: a study on spending on medication from the patient's perspective in Brazil. Rev Gestão \& Saúde, Rio de Janeiro, vol. 9, n. 2, p. 247-269.

Savanelli, M. C., Barrea, L., Macchia, P. E., Savastano, S., Falco, A. Renzullo, A. Scarano, E., Nettore, I. C., Colao, A. \& Somma, C. D. (2017). Preliminary results demonstrating the impact of Mediterranean diet on bone health. J Transl Med 15, 81. https://doi.org/10.1186/s12967-017-1184-x

Seghatoleslami, A., Afif A. H., Irandoust K. \& Taheri, M. (2018). The impact of Pilates exercises on motor control in middle-aged inactive women. Sleep Hypnosis 20, 262-266.

Seeliger C., Karpinski K., Haug A.T., Vester H., Schmitt A. \& Bauer J. S. (2014). Five free-circulating miRNAs and bone tissue miRNAs are associated with osteoporotic fractures. J. Bone Miner. Res. 29, 1718-1728. doi:10,1002 / jbmr.2175

Silva, L. H. F. M., Silva, J. M. M., Salama, M., Pneiro, L. G. P., Lunardi, F. O., Silva, P. G. B., Hirth, C. G., Lucena, I. F., Gomes, G. J. C. \& Milk, J. A. D. (2018). Cryopreserved ovarian tissue transplantation and bone restoration metabolism in castrated rats. Journal of the Brazilian College of Surgeons, [S.L.], v. 45, no. 1, p. 1-10. FapUNIFESP (SciELO). http://dx.doi.org/10.1590/0100-6991e-20181577.

Steihaug, O. M., Gjesdal, C. G., Bogen, B., Kristoffersen, M. H., Lien, G. \& Ranhoff, A. H. (2017). Sarcopenia in hip fracture patients: a multicenter crosssectional study. PLoS One 12: e0184780. doi: 10.1371/journal.pone. 0184780

Tarantino, U., Baldi, J., Scimeca, M., Piccirilli, E., Piccioli, A. \& Bonanno, E. (2016). The role of sarcopenia with and without fracture. Injury 47 (Suppl. 4) S3 - S10. doi: $10.1016 /$ j.injury.2016.07.057

Tatsuno, I., Terano, T., Nakamura, M., Suzuki, K., Kubota, K., Yamaguchi, J., Yoshida, T., Suzuki, S., Tanaka, T. \& Shoku, M. (2013). Lifestyle and osteoporosis in middle-aged and elderly women: Chiba bone survey. Endocr; 60(5): 643-50.

Van, Roie, E., Delecluse, C., Coudyzer, W., Boonen, S. \& Bautmans, I. (2013). High versus low external resistance strength training in the elderly: effects on muscle volume, muscle strength, and strength-speed characteristics. Exp. Gerontol. 48, 1351-1361. doi: 10.1016 / j.exger.2013.08.010

Westcott W.L. (2009). Strength training for frail seniors. J. Active Aging 8, 52-59.

Zupo, R., Lampignano, L., Lattanzio, A., Mariano, F., Osella, A. R., Bonfiglio, C., Giannelli, G. \& Pergola, G. (2020). Association between adherence to the Mediterranean Diet and circulating Vitamin D levels. International Journal of Food Sciences and Nutrition, [S.L.], v. 71, no. 7, p. 884-890. Informa UK Limited. http://dx.doi.org/10.1080/09637486.2020.1744533. 